\title{
EFFECTS OF THE LEGAL MAXIM: "NO HARMING AND NO COUNTER-HARMING" ON THE ENFORCEMENT OF ENVIRONMENTAL PROTECTION
}

\author{
Muhammad Shettima*
}

\begin{abstract}
Legal maxims are legal instruments that give a bird's eye view of the content of the law. Reflective of a consolidated reading of fiqh by great jurists over many centuries, legal maxims are a handy tool for researchers, lawyers, judges and legislators who need it to expand the grasp and understanding of the content and objective of the law. They also reflect settled principles of law to which jurists appeal when confronting new legal cases.

This paper explores the Prophetic hadith turnedmaxim, to reveal the dynamism of Islamic law towards prevention of environmental excesses and enforcement of legal protection by individuals or organisations. The maxim "No Harming and No Counter-harming" and its auxiliary maxims are appropriate legal instruments for legislations related to environmental protections.

The subject has been discussed based on the provisions of Qur'an, Prophetic traditions and their interpretation by scholars as relating to the general provisions of the Maxim. Limiting itself to one
\end{abstract}

Imam Malik Islamic Centre, Maiduguri, Borno State, Nigeria. 
universal maxim, the study aims to extend the regulations expounded in the above sources to contemporary environmental issues detailing legal injunctions against environmental harm and the removal of the existing ones.

Keywords: Legal maxims, environmental law, environmental rights, pubic rights, individual rights, prohibition of harm, elimination of harm, social responsibility, legal liability, compensation.

\title{
KESAN KAEDAH UNDANG-UNDANG "TIADA MUDARAT DAN TIADA MUDARAT BALAS” KE ATAS PENGUATKUASAAN PERLINDUNGAN ALAM SEKELILING
}

\begin{abstract}
ABSTRAK
Kaedah undang-undang adalah instrumen undangundang yang memberi pandangan mata burung kepada kandungan undang-undang. Mencerminkan fikah yang mantap oleh fuqaha yang ulung selama berabad-abad, kaedah undang-undang adalah alat yang berguna untuk penyelidik, peguam, hakim dan pembuat undang-undang untuk mengembangkan penguasaan dan pemahaman kandungan dan matlamat undang-undang. Kaedah undang-undang juga mencerminkan prinsip undang-undang yang mantap yang dirujuk oleh fuqaha apabila mendepani kes undang-undang yang baru. Makalah ini meneliti satu kaedah yang berasal daripada hadis Nabi, untuk menzahirkan kedamikan undang-undang Islam ke arah mencegah kelampauan terhadap alam sekeliling dan menguatkuasakan perlindungan undang-undang oleh individu atau pertubuhan. Kaedah "Tiada Mudarat dan Tiada Mudarat Balas" dan kaedah-kaedah tambahannya adalah instrumen
\end{abstract}


undang-undang yang sesuai untuk penggubalan undang-undang berkaitan dengan perlindungan alam sekeliling. Maksud umum kaedah tersebut telah dibincangkan berdasarkan kepada ayat-ayat alQuran, hadis-hadis Nabi dan tafsiran-tafsiran para ulama. Terhad kepada satu kaedah sejagat, kajian ini bertujuan untuk memanjangkan peraturan yang diperincikan dalam sumber-sumber di atas kepada isu-isu kontemporari alam sekeliling, dengan memperincikan injunksi undang-undang terhadap mudarat alam sekeliling dan penyingkiran mudarat sedia ada.

Kata kunci: kaedah perundangan, hak alam sekeliling, hak awam, hak individu, larangan mudarat, penyingkiran mudarat, tanggungjawab sosial, liabiliti undang-undang, pampasan.

\section{INTRODUCTION}

Islamic Legal Maxims (Al-Qawāidul fiqhiyyah) have been delineated as a discipline investigating branches of Islamic jurisprudence (fiqh) that are identical in depictions and legal implications, whether these branches are under the same or different subject matters. ${ }^{1}$ It is also marked out as legal principles that are general in nature, formulated in abstract phrases and consist of general Shari'ah injunctions which apply to matters that come under their themes. ${ }^{2}$ Though legal maxims are of general applications, they do have exceptions and these exceptions are often classified as subsidiary maxims or sub-maxims. Pragmatically, these submaxims are auxiliary maxims and so do not annul the general applications of the maxims which still remain the core.

Legal maxims are very imperative in Islamic jurisprudence as they encapsulate perceptions and precepts that can abet to figure out the factual essence of the Islamic Law in details. More importantly, they

\footnotetext{
1 Jumu’a, Imad Ali (1427), Al-Qawa'id al-fiqhiyya al-Muyassara, (n.p.), at 8.

2 Shilbi, Muhammad Mustapha (1422=2001), Al-Madkhal Fi al-Ta'reef bil Fiqh al-Islamiy, Darus-Salaam, Cairo, Egypt, at 324.
} 
ease to arrive at the apposite judgement where there is no direct verdict revealed on a specific matter. ${ }^{3}$

The four schools of Islamic jurisprudence are in agreement over five of the Islamic Legal maxims that they clasp within themselves the entire quintessence of the Islamic Shari'ah. They are depicted to be universal maxims for being all-inclusive and applicable to the entire range of fiqh without any specification; whereas the rest of the maxims are just elucidations of these five: ${ }^{4}$

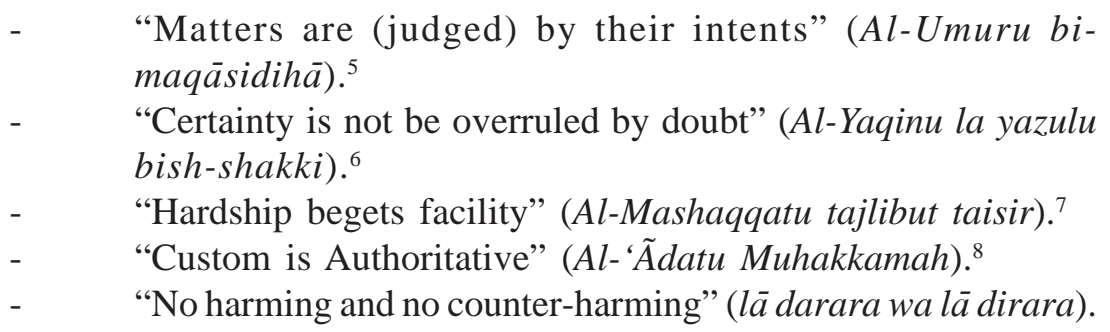

3 Cf. Hasanuzzaman, S. M(2007), Economic Relevance of Juristic Maxims, Scientific Publishing Centre, King AbdulAziz University, Jeddah, Saudi Arabia, at 3.

$4 \quad$ Kamali, M. H., Qawa'id Al-Fiqh: The Legal Maxims of Islamic Law. The Association of Muslim Lawyers UK. Retrieved 28th November 2010 from www.sunnah.org/fiqh/usul/Kamali_Qawaid_al-Fiqh.pdf. As-Sarkhasi, Abubakar, Muhammad bin Ahmad bin Abi Sahl, Al-Hanafi (d. 490H), Al-Mabsoot fil Fiqh al-Hanafi, Published 1406H by Dar alMa'rifa, Beirut, Vol. 6, at 59 and Vol. 19, at 139. As-Suyuti, Jalaal al-Deen Abdurrahiman bin Abi Bakr, Al'Ashbāh Wan nazā’ir Dar al-Kutub al-Ilmiyya Beirut, 1399H at 50. Al-Mabsoot Vol. 3, at 64, 77, Vol. 10, at 204.

$7 \quad$ Al-Izz bin Abdussalam, Imam Abu Muhammad AbdulAzeez bin Abdissalam, Qawa'id Al-Ahkaam fi Masalih al-Anaam, Dar al-Kutub al-Ilmiyya, Beirut (n.d.) Vol. 2, at 2-14. Ibn As-Subki, Taj al-Deen AbdulWahhab bin Abdil Kaafi As-Shafi'i, Al-Ashbaah wa al-Nazaa'ir. Edited by Sheikh Adil Ahmad Abdulmaujud and Ali Muhammad Iwad. Dar al-Kutub al-Ilmiyya, Beirut 2011, Vol. 1, at 48-49. Al-Zarqa, Ahmad bin ash-Shaikh Muhammad (1409H=1989), Sharh al-Qawa'id alFiqhiyya. Published by Dar al-Qalam, Damascus, Syria, at 105. Al-Ashbaah wa al-Nazaa'ir. Edited by Sheikh Adil Ahmad Abdulmaujud and Ali Muhammad Iwad. Dar al-Kutub al-Ilmiyya, Beirut 2011, Vol. 1, at 50-54. 
The author will briefly illuminate the meanings of this last universal maxim "no harming and counter-harming (lā darara wa là dirara)" together with its main sub-maxim: "Harm should be eliminated (Addararu yuzāl)” and highlight their environmental applications.

Thus the maxim: "no harming and no counter-harming (lā darara wa lā dirara)" proscribes all illegal forms of harm that may be inflicted by one person on another. Below are the auxiliary maxims that either elaborate the provisions of the maxim and/or limit its application according to its conditions:

1. “Repelling evil is preferable to securing benefit (Dar'ul Mafāsid aulā min jalbil Manāfi')."

2. "Harm does not establish precedent (Ad-Dararu lā yakunu Qadiman)."

3. "Private harm may be tolerated to prevent public harm (Yutahammalud Dararul Khāss li daf'id dararil 'Ãmm).”

While the maxim: "Harm should be eliminated (Ad-dararu yuzāl)" specifies inevitability of removal of all sorts of harms and its auxiliary maxims which elaborate it more are as follows:

$1 \quad$ "Harm should be eliminated within aptitude (Ad-Dararu yudfa'u bi qadaril imkān).”

2 "A harm is not eliminated with a harm (Ad-Dararu lā yuzālu bid-Darar)."

3 "A greater harm should be eliminated with a lesser harm (Ad-Dararul Ashadd yuzālu bid-Dararil Akhaff)."

\section{Significance of Legal Maxims in Environmental Protection Laws}

Due to excessive industrialisation that causes potential damage to health and livelihood of millions of people, environmental regulations have become a preoccupation for many countries across the world. Auspiciously, Islam, being the only religion with comprehensive way of life and established principles that preside over all spheres of human activities, has not left out an area that affects their well-being without providing guidelines towards its regulation. Legal maxims bring together scattered branches of fiqh into an assortment of abstract rules and thus make the entire 
branches and particulars of the Islamic law easily comprehendible; thereby saving time in researching injunctions of several matters that are otherwise spread over numerous chapters of Jurisprudence books. Moreover, legal maxims reflect objectives of the Shari'ah (maqāsidush Shari'ah). They are also conducive tools for ijtih $\bar{a} d$ and are set to be utilised as foundations for deducing legal injunctions of new occurrences (nawāzil). To this regard, Ibn Nujaim (d. 970A.H.) opined that a jurist will only get to the status of mujtahid or mufti by having perfect understanding of the maxims which is the stepladder for reaching the crest. ${ }^{9}$

\section{Instances of Modern Environmental Harms}

Due to industrialisation, many human activities in this day and age have created numerous environmental harms. ${ }^{10}$ These harms either affect the health of the population or their economic wellbeing. They also impinge on the bionetwork by causing dreadful damages in many parts of the world. Environmental harms/damages are mainly caused by economic activities which are primarily aimed at gaining benefits. Examples of such damage is the oil exploration in Nigeria's Niger delta region which has over the years caused health problems such as respiratory diseases, skin lesions, hindering access to food and clean water, etc. These damages to the nation's economy and the health of its populace can appropriately be addressed and prevented through legislation of efficient environmental laws. Islamic legal maxims have heaps to contribute in this vicinity. This article attempts to illumine the effects of the Shari'ah maxims on

$9 \quad$ Al-Mar'ashli, Muhammad Abdurrahman, Tatawwurul Qawā'idil Fiqhiyya min Dhahira ilā 'Ilm wa Atharu dhalika fil Fiqhl Islamiyy, Beirut, Lebanon, at 23.

10 The surroundings in which we live all living and non living materials are called our environment. The factors or pollutants which cause disturbance in natural environment are called pollution. Ecosystem (The natural process of producers and consumers) is destroyed due to some harmful human activities is called Pollution. Pollution is a kind of harmful effect of the excess use of chemicals and energy resources like heat, light, sound etc. (History and Causes and Environmental Pollution by Sajid Sindhu. Retried from http://ezinearticles.com? expert=Sajid_Sindhu on: 4/4/2011. 
enforcement of environmental regulations and explains their noteworthiness for legislators in setting up effective regulations to protect the environment.

In the subsequent pages, the author will explicate the meanings and applications of the maxims "no harming and no counter-harming" and its auxiliaries (mentioned above) as they relate to environmental issues.

\section{MAXIMS PROHIBITING HARMING OR CAUSING OF HARMS}

\section{The Maxim}

"No harming and no counter-harming (là darara walà dirāra)" 11 is one of the five Universal Legal Maxims. Its phrasing is excerpt of a prophetic Hadith graded hasan. ${ }^{12}$ In a similar Hadith transmitted by Tirmidhi (d. 279A.H.) and Abu Dawud (d. 275A.H.), we are informed that the Prophet, peace and blessing of Allah be upon him, has said: "He who causes harm to a Muslim, will be harmed by Allah."13

$11 \quad$ As-Sarkhasi, Abubakar, Muhammad bin Ahmad bin Abi Sahl, Al-Hanafi (d. 490H), Al-Mabsoot, Published 1406H by Dar al-Ma’rifa, Beirut, Vol. 16, at 81. Al-Borno, Muhammad Sidqi bin Ahmad bin Muhammad (1416=1996), Al-Wajiz fi Iydāh al-Qawā’id al-Fiqhi al-Kulliyya, Mu’assasatur Risāla, Beirut, at 251. and Al-Borno, Muhammad Sidqi bin Ahmad bin Muhammad (1424=2003) Mausu'at al-Qawa'id alFiqhiyya, Resalah Publishers, Beirut, Lebanon.Vol. 8, at 873.

Based on reliability, memory of reporters and consistency, hadith is categorised into sahih (sound), hasan (good), da'if (weak) or maudu' (fabricated, forged) (http://www.sunnahonline.com/ilm/sunnah/ 0008_page4.html). A Hasan (good) grade hadith is the one where its source is known and its reporters are unambiguous but whose ability to memorise is not as strong as that of saheeh (sound) (Retrieved from http://muttaqun.com/scienceofhadith.html on 4/5/2011). See also: Al'Uthaimeen, Muhammad bin Saleh, Sharh Al-Baiqooniyya fi sharhi al-Hadith. Ed. By Sayyid bin Abbas Al-Jalili, Maktabatus Sunnah, Cairo, 1415=1995.

13 Al-Albani, Muhammad Nasirudin, Silsilatul Ahādithus Sahihah, Maktabatul Ma’ārif, Riyādh, KSA, Vol. 1, at 498. 
In a nutshell, the maxim prohibits Darar and Dirär. Darar means inflicting harm on any one initially whereas Dirār means harming in retaliation or retribution, ${ }^{14}$ i.e. countering his harm with harm. On the other hand, some jurists have defined Darar as inflicting one with a detriment ${ }^{15}$ and/or preventing him/her from enjoying his/her legal rights. ${ }^{16}$ This maxim implies prohibition of all sorts of private and public harms. In other words, the maxim forestalls harm before they take place and urges their removal if it occurred. ${ }^{17}$

This maxim is supported with evidences in Qur'an and Sunnah dictions revealed as general provision or in relation to specific cases in which we are being edified that commission of harm is prohibited.

Allah the Almighty said: "but do not take them back to injure them," ${ }^{18}$ He also said: "No mother shall be treated unfairly on account of her child"19 and He said: "Deal not unjustly, and ye shall not be dealt with unjustly." 20

These verses prohibit causing harm against each other in any form, by any means and at any time. Islam prevents evils before they occur by laying down laws controlling peoples' behaviour in utilization of accessible resources. Allah the Almighty tells us about His punishments to men who fail to abide by such law: "Mischief has appeared on land and sea because of (the meed) that the hands of men have earned that (Allah) may give them a taste of some of their deeds: in order that they may turn back (from Evil)." ${ }^{21}$ Atā (d. 114A.H.), the famous scholar among successors (tābi’un), said: “Appearance of mischief is by

$14 \quad$ Az-Zarqa, Ahmad bin ash-Shaikh Muhammad (1409H=1989), Sharhul Qawa'id al-Fiqhiyya. Published by Dar al-Qalam, Damascus, Syria, at 165.

15 Al-Haithami, Ahmad bin Muhammad bin Hajar (n.d.). Fat'hul Mubeen fi Sharhil Arba'in, published by Isa Al-Halabi, at 237. Ar-Rāzi, Fakhr al-Din Muhammad bin Umar bin Husain (1981), AlMahsuul Fi Ilm Usul al-Fiqh Muhammad bin Sa’ud Islamic University, Vol. II, part 3, at 143. Cf: Mausu’atul Qawa'idil Fiqhiyya wad-Dawabit al-Fiqhiyya al-Hakimah lil Mu'amalat al-Maliyya at 54.

18 Qur'an 2:231.

19 Qur'an 2:233.

20 Qur'an 2:279.

21 Qur'an 30:41. 
shortage of rainfalls, fruits and incomes as well as by total droughts ${ }^{22}$ including regular floods, deadly forest fires, deadly hurricanes, unfamiliar illnesses such as Aids, cancer, etc. ${ }^{23}$

The following examples illustrate prohibition of environmental harms under this maxim:

1. Any action that will infringe environmental rights of an individual, such as preventing him/her from enjoying right of water supply from a nearby river to his/her farm, ${ }^{24}$ dumping of waste and lethal chemicals into his/her backyard or public space, ${ }^{25}$ is prohibited as provided by the Hadith: "no harming and no counter-harming."

2. Actions that flout the sanctity and safety of the environment, such as cutting down of trees or causing death to wildlife unnecessarily, is ascetically prohibited by this maxim. The Prophet, peace and blessing of Allah be upon him, has warned against deforestation in his saying: "whosoever cuts a lote-tree, Allah will direct his head towards Hell fire. ${ }^{{ }^{26}}$ Abu Dawud said, it means whosoever intentionally, without any legal justification, cuts off a lote-tree used as shade by travellers and animals in a desert, his head shall be directed to Hell-fire. ${ }^{27}$ The Prophet, peace and blessing of Allah be upon him, has advised his companions to refrain from all unnecessary actions during Jihad as its objective is to eliminate harm not to establish it; and thus commanded: "do not to cut off trees, do not kill animals you do not need and avoid harming believers." 28 Qur'ānil Azim, Published by Darut Tibah, 1420H=1999, Vol. 4, at 435. Al-Khayyat, AbdulAziz Izzat, Al-Bi’ah wal Hifāzu alaihā min manzurin Islamiy, Nineteenth Round of Mujamma'ul Fiqhil Islamiy Ad-Dauliy, 1429/2008, Sharja Emirate, UAE, at 7. Abu Dawud, Sulaiman bin Al-Ash’ath As-Sijistāni, Sunan Abi Dawud, Edited by Kamāl al-Hut. Beirut, Darul Hanān 1409=1989, Hadith No. 3016. Az-Zarqā, at 102. 
3. It is mentioned in a Hadith narrated by $\mathrm{Jabir}^{29}$ that the Prophet, peace and blessing of Allah be upon him, has disallowed us to ease ourselves in still water not to make it unusable. This Hadith, by extension, is applicable to spilling of industrial wastes and toxic chemicals into rivers or burying them in terrains by water, farms, residents, etc. Moreover, the maxim: "no harming and no counter-harming" authenticates the prohibition of spilling hazardous substances which is more harmful than urinating in stagnant water.

4. Prohibition of wastefulness (Isräf) which is utilization of available resources extravagantly i.e. beyond one's common needs; thereby harming the environment and others who could not meet their mere basic needs. The Holy Qur'an provides that: “But squander not (your wealth) extravagantly. Verily the extravagant ones are brothers of the Satans; and the Satan is ungrateful to his Lord.” ${ }^{30}$ Similarly, the Prophet, peace and blessing of Allah be upon him, has commanded to use water economically even for religious obligations ${ }^{31}$ what if it is used for other purposes.

5. The maxim: "no harming and no counter-harming" also bans the use of one's own property in a way that causes harm to his/ her neighbours. For instance, establishing a bakery or any other heavy machinery amid residential quarters is prohibited. ${ }^{32}$ In an account attributed to Qadi Ibn Al-Qāsim (d. 191H), a man wanted to erect a smeltery by the walls of his neighbours; but scholars ruled that the neighbours have the right to stop him seeing that

al-Arnā'ut, First published by Mu’assasatur Risāla 1408, 239-240, Hadith No. 213.

An-Naisaburi, Muslim bin al-Hajjā, Sahih Muslim, Published by Daru Ihyā’it Turāthil Arabi, Beirut, n.d., Vol. 1, at 235, Hadith No. 281.

30 Qur'an 17:27. 
his project is associated with harms like: noise, smoke and probable fire break out. ${ }^{33}$

In the same way, poisonous gases released from contemporary chemical and oil industries causing health problems, polluting farmlands and water supply are banned by this maxim.

6. Since the provisions of this maxim are applicable to all sorts of harms, it can fittingly control environmental harms which are this era's area of apprehension. Ibn Abdul Barr (d. 463A.H.) reasoned that one can apply the provisions of the maxim to all cases that have similar implications and that this is the right ruling in sha'a Allah. ${ }^{34}$

It is the charge of Muhtasib to supervise and enforce the Sharia provisions which forbid harms emanating from individuals, workshops, firms, etc by regulating their locations, working conditions, etc so that the Sharia injunctions are not broken..$^{35}$ It is also his responsibility to enforce removal of wastes in public areas as has been directed by the Prophet in his saying: "faith includes over seventy articles; the bottommost is removal of harm on the street and topmost is the saying of no god but Allah.”36 This is the responsibility of the public to be enforced by the authorities.

\section{The auxiliary maxim:}

"Repelling an evil is preferable to securing benefit" (Dar'ul Mafäsid aulã min jalbil Manäfi') bears out that “don'ts" are put ahead of “dos" because acquisition of benefits and prevention of evils is one of the basic objectives and norms of the Islamic Sharia. As a result, whenever there is a clash between benefit and harm, the harm is not ignored in most

\footnotetext{
$33 \quad$ Ibid.

34 Cf: Al-Qurtubi, Yusuf bin Abdillah bin Abdil-Barr, At-Tamhid limā fil Muwatta' minal Ma'āni wal-Asānid, edited by Mustapha bin Ahmad Al-Alawi, Published by Mu'assasatur Risālah, n.d., Vol. 2, at 161.

35 Cf: Al-Fās, Abdurrahman, Khuttatul Hisbah fin Nazari wat tatbiqi wat tadwin, Published by Daruth Thaqāfiyya 1404-1984, at 30.

36 Al-Albani’s Silsilatul Ahädith As-Sahiha, Vol. 4, at 369, Hadith No. 1769.
} 
cases but the benefit may be disregarded. In other words, harms are not overlooked even if there are benefits. By this fact, mills and ovens releasing heavy smokes were banned to be built amid residential vicinities despite their benefits. ${ }^{37}$ This injunction is applicable to modern industries and factories causing environmental harms even though they provide employment opportunities and other benefits. However, the value of health of the population and their well-being will not be jeopardized for the benefit of few shareholders of an industry.

\section{The auxiliary maxim:}

"Harm does not establish precedent (Ad-dararu lā yakunu Qadiman) $)^{38}$ is an exemption from the maxim: "Let the ancient rest on its age." (Al-Qadimu yutraku alä Qidamihi). ${ }^{39}$ This auxiliary maxim obligates that getting rid of harms is a priority no matter how aged it is, particularly if they affect the general public. This is significant for protection of the environment, and thus can be concluded that:

i. Waste disposals that pollute public passages should be eliminated without regard to the length of time they have been in existence.

ii. This also includes chemical spillages from dying cottage industry dumped into rivers and drainages which affects the ecosystem, the life and safety of human beings and animals.

iii. Incidents of ecological pollutions by industries set up without prior objections have been narrated in fiqh Literatures. Al-Qadi Ibn Abdur-Rāfi' (d. 733H) ruled that such pollutants should be terminated and eliminated instantly irrespective of being simple or complex or being recent or aged because these are not reasons to validate continuance of their harms. ${ }^{40}$

\begin{tabular}{ll}
\hline 37 & Az-Zarqā, at 225. \\
38 & Az-Zarqani. Sharh Al-Qawa'id, at 55. Al-Wajiz at 178. \\
39 & Al-Wajiz at 178. \\
40 & Cf. An-Najimi, at 13.
\end{tabular}




\section{The auxiliary maxim:}

Private harm may be tolerated to prevent public harm (Yutahammalud Dararul Khāss li daf'id dararil 'Ãmm) ${ }^{41}$ is applied where there is clash between public harm and private harm. In such instances, the private harm may be tolerated in order to protect the public interest. ${ }^{42}$ The general rule is: "Harm should be eliminated" but whenever there is clash between a public and private harm, the law tolerates the private harm which mostly have limited impacts, as the damages of public harms are usually widespread. Example, where activities of a mining company causing damage to the environment making the life of a nearby settlement difficult and/or polluting their natural resources, such as water resource. The company will be forced to stop such activities. Though banning the company from its business harms its stakeholders and employees but the maxim enunciates that the general public should not suffer because of gains of the owners.

\section{MAXIMS DEALING WITH ELIMINATION OF CAUSED HARMS}

The maxim: "Harms should be Eliminated (Ad-dararu yuzāl) ${ }^{43}$ is the most appropriate instrument to address modern environmental disasters caused by people and industries; thus the precision of this maxim requires no further highlighting.

Yet, we have to cite further that the general rule in Islam is the protection of people's right even if that requires use of force. In no circumstance, Islam allowed violation of other's rights; nonetheless, such violations are not condoned by Allah unless the victim pardons the violator. The Prophet, peace and blessing of Allah be upon him, said: "Verily,

\footnotetext{
41 Ibn Nujaim's Al-Ashbā'h Wan-Nazā'ir at 87, Al-Wajiz, at 263.

42 Al-Alfi, Muhammad Jabr, Al-Bi'ah wal Muhāfazatu alaiha min Manzurin Islamiyy. Nineteenth Round of Mujamma'ul Fiqhil Islamiy Ad-Dauliy, 1429/2008, Sharja Emirate, UAE, at 12.

43 As-Suyuti's Al-Ashbāh wan-Nazā'ir at 83, Ibn Nujaim's Al-Ashbāh at 85, Al-Borno’s Mausu'atul Qawā'id al-Fiqhiyya, Part 6, at 261.
} 
rights will be delivered to their owners on the Judgement Day until the right of a non-horned goat is retrieved from the horned goat." 44 The Sharia provisions that prohibit infliction of harm against each other also imply compulsion of its removal but in different forms as can be seen in the following:

1. Jurists have talked about the obligation to remove clay beneath rivers and maintenance of its shores. ${ }^{45}$ It is therefore by extension obligatory to remove refuse-dump areas in areas they are deemed harmful as they may cause damages. Consequently, elimination of huge harms is an obligation of the governments and the eradication charges should be paid from the public treasury (Baitul Mãl) since it is in the public interest. Even if resources in the treasury are not sufficient, elimination of harms remains an obligation on leaders by any possible means; even by forcing their people to remove it or taxing them for the expenses if the elimination requires expertise. ${ }^{46}$ Likewise, if an individual dumps a harmful refuse, he/she should be forced to remove it by the hisbah.

2. Where dumped refuses or pollutants cause damage to one's property, health or livelihood, the violator should be held liable (dāmin). ${ }^{47}$ The Prophet, peace and blessing of Allah be upon him, said: "The hand is liable for what it has taken until it returns it back." 48

$\overline{44} \quad$ Al-Bukhari, Muhammad bin Ismā’il bin Ibrāhim bin Al-Mughirah, AlAdabul Mufrad, Edited by Muhammad Fu'ād Abdul Baqi, Published by Dārul Bashā'iril Islamiyyah, Beirut, 1409=1989, at 183. See also: Muslim, vol. 4, at 1998, Hadith No. 2582;

Al-Mausu'atul Fiqhiyya al-Kuwaitiyya, Published by Matābi' Dāris Safwah, Egypt, n.d., Vol. 25, at 373.

An-Nawawi, Muhyiddin Yahyā bin Sharaf, Raudatut Tālibin wa Umdatul Muftin, Al-Maktabul Islamiy, Beirut, Lebanon 1405H, Vol. 5, at 306 .

47 See: Al-Jauziyya, Muhammad bin Ayyub Azzar'i Ibn Al-Qayyim, I'lāmul Muqi' 'in an Rabbil Ãlamin, Edited by Tāha Abdurra'uf Sa'ad, Published by Dārul Jil, Beirut, 1973, Vol. 2, at 355. Also see: Al-Izz's Qawā'idul Ahkām Vol. 2, at 266. 
3. Where harm causes several damages, the violator shall be responsible for all the damages. ${ }^{49}$

4. Where harm leads to loss of life, the harm should be immediately eliminated; and also depending on the role played by the violator, he shall be held responsible based on the provision of the Holy Qur'an: "We ordained for them therein: "life is for life, eye for eye, nose for nose, ear for ear, tooth for tooth and for wounds equal retribution..." 50

Moreover, where death is caused by mistake, compensations are to be paid to the family of the victim as Allah the Almighty has provided in Qur'an: "If one (so) kills a believer, it is ordained that he should free a believing slave, and pay compensation to the deceased's family, unless they remit it freely." 51

5. Shafi'is and Hanbalis are of the view that where a person allows his gutter to spill out and cause damage to other's property or cause loss of lives, he shall be held liable even if he/she was allowed by authorities concerned to do so.

Similarly, if someone keeps mud on the roof of his dwelling with the aim of repairing it, but due to unforeseen circumstances, it spilled on someone and killed him/her or caused death of animals, the house possessor shall be liable for the deaths and compensations. ${ }^{52}$

The Hanafis differed in such circumstance however, they said, if that occurred after permission from authorities, he will not be liable since it was the victim that approached the property:53 while the Maliki school is of the view that there will

Tirmidhi), Edited by Basshar Auwad Ma'ruf, Published by Darul Gharb Al-Islamiy, 1998 Vol. 3, at 566, Hadith No. 1266. Sheikh Al-Bani said it’s a weak hadith (see Da'iful Jami', Hadith No. 3737).

$49 \quad$ Al-Mausu'atul Kuwaitiyya, Vol. 28, at 225.

50 Qur'an 5:45.

51 Qur'an 4:92.

$52 \quad$ Al-Mausu'atul Fiqhiyya Kuwaitiyya, Vol. 28, at 352.

53 Ibn Hammam, Kamaluddeen Muhammad bin AbdilWahid As-Siwāsi, Fathul Qadir, Darul Fikr, Beirut, Vol. 7, at 246. 
be no legal responsibility in such instances, whether or not the authorities have permitted that. ${ }^{54}$

6. This is also applicable to damages done to manäfi' i.e. benefits of all sorts in terms of service, products or whatever. It implies that all beneficial public properties should not be damaged by any means, by any person and at any time. ${ }^{55}$ Otherwise, the party causing the damage shall take the liability involved according to most jurists.

\section{(1) The auxiliary maxim:}

"Harm should be eliminated within aptitude" (Ad-dararu yudfa'u bi qadaril imkān) ${ }^{56}$ is a limitation of the maxim "harm should be eliminated". Elimination of harms is a general legal obligation on each and every Muslim according to his/her capability. Allah said: "On no soul doth Allah place a burden greater than it can bear." ${ }^{57}$ In view of this, environmental protection law should be practised by all and sundry rightfully.

Harm, in the first place, should not be allowed to occur. If it occurs, however, it should be eliminated. Besides, letting it to reside is violation of the Shari' ah law. All legal means should be explored in order to remove it in the most appropriate manner, as has been discussed above.

An example of its application could be cited thus, industrial wastes that cause death or incurable ailment, and thus the victims of such incidents should be compensated according to the Islamic injunctions, in order to ease the damage inflicted upon them.

\footnotetext{
$54 \quad$ Attarabulsi, Shamsuddeen Muhammad bin Muhammad, Mawāhibul Jalil li Sharhi Mukhtasaril Khalil, Published by Daru ālamil Kutub, n.d., Vol. 5, at 183.

55 Cf: Al-Mausu'atul Kuwaitiyya Vol. 28, at 225.

56 Majalla Art. 30, As-Suyuti. Al-Ashbāh Wan-'nazā'ir. at 83, Ibn Nujaim’s Al-Ashbāh, at 89. Al-Borno's Al-Wajiz at 256.

57 Qur'an 2:286.
} 


\section{The auxiliary maxim:}

"Harm should not be eliminated with a similar harm (Ad-Dararu la yuzälu bid-Darar)" ${ }^{\text {58 }}$ is an implication of the second part of the maxim: "no harming and no counter-harming." Harm should be eliminated but not with a similar harm or with a greater harm. This auxiliary maxim is important when introducing new measures to curtail environmental problems, for instance; and thus it should not be blindly carried out until all consequences of such measures are carefully studied and their effects are properly analysed. An example of this is the introduction of bio-fuel to reduce dependence on fossil fuel, which according to the United Nations "large-scale land acquisitions by foreign investors for bio-fuels is squeezing land suitable for agriculture." ${ }^{\text {99 }}$ World Bank policy research working paper released in July 2008, ${ }^{60}$ confirms that bio-fuels have raised food prices between 70 to $75 \%{ }^{61}$ and harmed many poor people across the world.

\section{(3) The auxiliary maxim:}

“Greater harm may be eliminated with a lesser harm” (Ad-Dararul Ashadd yuzālu bid-Dararil Akhaff) ${ }^{62}$ means that a greater harm should be eliminated with a lesser one provided the lesser harm will not generate a graver harm than the one intended to be eliminated. If elimination of harm will produce another harm equivalent to it in gravity, the initial harm should not be eliminated until when it can be done away with aptly.

\footnotetext{
58 As-Subki. Al-Ashbāh Wan-Nazā’ir, Vol. I, at 42. Mausu’atul Qawā’id al-Fiqhiyya Part VI, at 257.

59 http://www.mg.co.za/article/2010-10-26-global-food-crisis-forecast-asprices-reach-record-highs.

60 Donald Mitchell (July 2008). “A note on Rising Food Crisis” (PDF). The World Bank. http://www.worldbank.org/external/default/ WDSContentServer/IW3P/IB/2008/07/28/000020439_20080728103002/ Rendered/PDF/WP4682.pdf. Retrieved 2008-07-29. Policy Research Working Paper No. 4682.

61 http://en.wikipedia.org/wiki/2007\%E2\%80\%932008_world_ food_price_crisis.

62 Ibn Nujaim. Al-Ashbāh Wan-Nazā’ir , at 89. As-Suyuti, at 87, Al-Borno’s Al-Wajiz at 260, and Al-Borno’s Mausu’a Vol. 6, at 253.
} 
This auxiliary maxim is similar in meaning to the earlier auxiliary maxim that reads: "harm should be eliminated within aptitude."

This obliges authorities to provide precautionary measures preventing long-term effects of activities like logging, such as creating legal responsibilities on industries to plant new trees and take care of the plants until growth on repetitive schedules. This is in line with a Prophetic tradition also used as maxim, i.e. "He who makes profit, takes the responsibility" (Al-Ghurmu bil Ghunmi). ${ }^{63}$

Moreover, Prophet Muhammad, peace and blessing of Allah be upon him, said: "If the last Day approaches while one of you holds a palm-shoot and he is able to plant it before it comes, let him plant it." 64 This Hadith, by extension, symbolises obligation of doing beneficial things to the environment by planting trees even at the last seconds of one's life.

\section{CONCLUSION}

The abstract and synoptic stance of the Islamic Legal maxims gives them elevated level of elasticity and agelessness; and thus makes them related to all current global issues including environmental laws. The maxims: "no harming and no counter-harming" and "harms should be eliminated" together with their subsidiaries prohibit causing of harms in whatever form, by any person and at any time. These provisions provide guidelines for elimination of damages caused to environment and also demonstrate the versatility of the Islamic Sharia and its applicability to all matters at any imminent era.

Although the paper dealt with the afore-mentioned maxims and sub-maxims in relation to Islamic environmental law, it also suggests that a larger work can decipher the relevance of many other maxims to the environmental guidelines. Such works, under different spheres of knowledge, will prove the response of the Islamic law to all new issues.

\footnotetext{
$63 \quad$ Al-Borno’s Al-Wajiz, at 365.

$64 \quad$ Al-Adabul Mufrad Vol. 1, at 168. No. 479.
} 